\title{
Of Mice and Museums: The Changing Practices of doing Museums
}

\author{
Lectio praecursoria at the University of Helsinki 15.10.2021
}

\author{
Inkeri Hakamies
}

$\mathrm{M}$ arketization - the introduction of competition into the public sector - and digitalization of society, are two epochal changes that have emerged during my lifetime, penetrating a major portion of our everyday activities (Borowiecki, Forbes \& Fresa 2016, xx). Cultural institutions have not been immune to these changes: Museums today need marketing strategies, outreach programmes, and digital collection management tools - things that were quite unheard of some decades ago. How have these transformational changes affected the function and perception of museums, and the people who work for them? These two questions go hand in hand, because it is impossible to separate a museum from the people who work for it. They decide the "what" and "how" of the exhibitions and shape the public image of their institutions. Their practices create museums.

So how have the social practices and professional identities of museum workers changed in the last decades? What practices do they consider meaningful, how has this perception changed, and how might it create hierarchies between the "right" and "wrong" kind of museums? These are the questions I have tackled in my dissertation, using empirical research materials, namely recorded interviews with museum professionals and questionnaire answers from museum visitors. The material tells a story of the Finnish museum field of the late 20th and early 21 st centuries, and how it changed in that time.

As I have described in the introduction to the dissertation, my research task began to really take shape when I presented the first draft of my first article in the ethnological research seminar. I received friendly and reasonable advice from a fellow PhD-student to include a definition of museums and their functions in my text, and perhaps refer to the definition by the International Council of Museums - which states that museums are public, permanent and non-profit institutions etc. (ICOM 2007). This is not at all uncommon in museological literature, as it is an easy way to let your readers know what you are talking about when you talk about museums and it ensures them that you commit to some shared standards and ethics. However, I was reluctant to do so. I realised the reason for this was that I felt museums represented many different things for the people in my research material, and I wanted my readers to see these different ways a museum could be understood. Some of the views of the interviewees and questionnaire respondents were in line with the 'official' definitions 
of a museum, but others more or less explicitly challenged them, meaning there were different ways of defining 'museal' in different contexts. I did not want to fix the definition of a museum by referring to the authority of ICOM, but wanted to explore how museums as cultural phenomena were understood and reproduced in practice.

I do believe that the museum field in general needs shared standards and guidelines, but as a cultural researcher, I also recognise the plurality of museum practices, and in my dissertation, I interpret them within the practice theory framework as "things that people do" that have shared meanings to the practitioners (Reckwitz 2002, 249; McCarthy 2015, xliii-xlv). Thus, the "things that people do" in museums might be controlled by rules that are set from above, but it does not change the fact that individual museum institutions and work communities within museums also have their own traditions. Museum professionals of the $21 \mathrm{st}$ century still carry a lot of tacit information regarding their work (Robbins 2020,60). The practical knowledge the museum professionals have accumulated during their careers reflects norms, values and ideals, and ideas of a museum.

\section{Entering the Meta-Museum}

During my research I have tried to outline and visualise the history of changing museum practices by imagining a museum exhibition about museums. I have found the mental image of the museum of a museum very helpful: When I imagined putting the practices under the spotlight and considered how best to explain them in terms of both objects and words, as somehow isolated entities that can be studied, the ordering of museum history became more manageable.

To my delight, just this autumn, the museum Aboa Vetus \& Ars Nova in Turku, Finland, is hosting a temporary exhibition called the Mouseum. It is a miniature museum for mice, built by the local Raunistula dollhouse club. This about 4-meter-long work consists of seven parts or room boxes: the façade and entrance to the museum, the museum shop, the exhibition room, a café, an atelier, the workshop of the museum technician, and the backyard. The doll-sized felted mice can be seen meeting and greeting their friends, buying souvenirs and art supplies in the museum shop, visiting the special exhibition called "Say Cheese", sketching a live model in the atelier, and sitting at the museum café. The scene at the backyard - an archaeological excavation and a sculpture of an elephant - clearly refers to the real-life museum Aboa Vetus \& Ars Nova, which also combines the fields of art and cultural history.

Actually, dollhouses and museums have a lot in common. As we know, historically dollhouses and miniature worlds have not been intended for children or for play, although there are also well-known theories about dollhouses as pedagogical tools that can be used to teach young girls about domestic chores (Kuurne 2010, 7-13; Lönnqvist 2011, 180-181). Bo Lönnqvist, professor emeritus of European Ethnology, has pointed out that the earlier dollhouses showed idealized interiors complete with detailed furnishings, household items and art pieces, and represented the finest craftmanship, and they were status symbols put on display for admiration by adults, and served as entertainment. As cultural objects, Lönnqvist compares these dollhouses to the 16th century cabinets of curiosity, also known as Kunstkammern, or Wunderkammern - small collections of extraordinary objects, which attempted to categorise and tell stories about the wonders and oddities of the natural world, and were one of the earlier versions of modern museums (Lönnqvist 2011, 184-187). 
Museums have also employed miniature models later on for pedagogical purposes: As recent museological studies have shown, even though the credibility of museum collections is often bound up with their authenticity, museums actually hold many copies and models, across the disciplinary spectrum (Alberti, Blackwell, Davidson, Goldberg \& Swinney 2019, 13). For example, the 18th and 19th century scholars and expeditioners might have commissioned miniature-sized reproductions of the things that they saw during their fieldwork trips. The smaller models were easier to bring home and enabled the presence of objects that could not otherwise be exhibited in museums. As Brita Brenna has discussed, the models that museums possess are used to denote representations of something real, and in Brenna's words, they "made something absent present; their materiality carried their cargo" (Brenna 2019, 31). However, models also denote what we could call a prototype, and they are thus also tools for inspecting something or figuring it out (Brenna 2019, 30).

The Cabinets of Curiosity, miniature copies, and renaissance dollhouses are all examples of expressing the European way of reasoning in a material form: they represent a worldview of classification and systematic organization based on empiricism, that is, observation and experimentation, as well as scientific ambitions to represent totalities (Lönnqvist 2011, 185). A dollhouse is a material encyclopaedia of home, and a way of understanding and peeking into an imagined everyday life. In this, museums and dollhouses are alike: they allow us to take a look into the lives of others - or ourselves. Therefore, a miniature or dollhouse museum is a real meta-museum that not only allows us to peek into the everyday happenings of an idealized museum, but it also manifests the whole western tradition of making sense of the world through the representation of material objects.

\section{From Reepicheep to Mickey Mouse: The "Disneyfied"1 Museums}

The Mouseum, although its many details clearly refer to a real-life museum in Turku, is from a fantasy world and not a miniature model or copy of any particular museum. It is an example of what Marcus Boon has called "a simulated museum", which imitates "the style and form of various extant museums" (Boon 2019, 261). But in my opinion, it also embodies an idealised image of a contemporary museum: The Mouseum is a museum that has embraced the market economy and aims to be people-pleasing. As ethnologists Lizette Graden and Tom O'Dell have discussed in several publications, museums have increasingly adapted - or have been forced to adapt - to the business models of the private sector (Gradén \& O'Dell 2018a, 450; Gradén \& O'Dell 2018b, 57-58). Museums nowadays might worry that they are being bypassed as boring, dusty places, and they are under pressure to attract more visitors who are expecting to be entertained and to gain cultural capital by investing their time and money at museums (Kirschenblatt-Gimblett 1998, 139). Graden and O'Dell have argued that museums are thus forced to produce "hip heritage" - heritage that is seen as a fashionable commodity with market value (Gradén \& O'Dell 2018b, 46).

In the Mouseum, the combined commercial space is bigger than the exhibition space. The atelier is perhaps not strictly commercial, but it is a stage where the museum can provide engaging experiences to its audiences. The ways in which economical pressure to give museum visitors what they want has affected museum practices raises ethical questions,

1 For discussion about the effects of "disneyfication" on museums that are trying to compete in the experience economy, see e.g. Kalin 2016. 
but it could also be perceived as part of museums' long democratization process. I do not mean to criticize the Mouseum or any other museum that strives to be more popular. The Mouseum is clearly a museum that serves its local community and has a meaningful purpose, and its audiences are engaged in the museum's activities, by taking art courses, for example, and thus entering the field of producing art themselves.

The Mouseum is at the same time a very modern, audience-based institution, and on the other hand, a very traditional sort of museum - one might even say: stereotypical. As Laurajane Smith (2015) has pointed out, people usually know beforehand what they want from museums, and rather than being challenged, museum visitors tend to seek confirmation for their own beliefs. This might mean that they always expect to see the same objects in museums, or that exhibitions should follow the same choreography. For example: Great part of the artworks in the Mouseum's exhibition are also so-called classics. There are miniature versions of portraits by Frida Kahlo, Leonardo da Vinci, Helene Schjerfbeck and other Finnish masters - paintings that are easily recognisable as something one might expect to see in a museum. There are also works that might be commenting of the whole discourse of "what is art": it is difficult to tell, whether the piles of cheese on the pedestal are meant to be admired or consumed.

What I find interesting, is that there indeed are styles or forms of a museum - one could also call them museum practices - that are so generally recognised as museal or museum-like, that they inspire imitations or even parodies.

However, what is missing at the Mouseum, is historical contextualisation. I argue that one of the reasons for the frequently heard statements about the dustiness of museums is that people cannot distinguish the past of museums from their current form. One of the principal tasks of museums is to preserve the tangible and intangible cultural heritage, but museums themselves are not immutable. The practices that people carry out in museums, and the ways of doing and defining a museum, have been continuously evolving throughout the museum history. The Mouseum simulates a popular image of a contemporary, participatory, un-dusty and "hip" museum seemingly well, but it also makes it clear, that the ideal museum has not looked the same for everybody. For the museum professionals whose interviews I've analysed and who started their careers in the 1960s and 1970s, the ideal museum comprised of research and hands-on work with museum collections, and doing inventory in the museum storage rooms was a way to learn the tricks of the trade in practice - whereas in the Mouseum there is no storage nor office space except for the workshop, and the only employees that can be spotted on the scene are the museum technician, who seems to be responsible both for conserving the collections and executing exhibitions, and the keepers of the museum café and shop.

\section{Joining the Mischief of Ethnologists}

In reality, we cultural researchers do not study mice, and we seldom get to materialize our research outcomes. Instead, we use words to create miniature worlds that fit into the size of a book. Whereas museums have stored material evidence of our culture for future generations, ethnographic research has recorded their written descriptions. Therefore, the terminology that we use, matters. In her lectio praecursoria about 13 years ago, Leena Paaskoski, another ethnologist, stated that joining a profession includes learning the traditions, 
practices, values and "grammatics" of that professional group (Paaskoski 2009, 1). Referring to the ideas of Oili-Helena Ylijoki, she compares this process to being socialized into a tribe, which might mean going through certain initiation rites, and at the end of the process you can consider yourself a full member of said tribe. She also points out that each new member joins the tribe or group through their own path, having a different background and perspective (Paaskoski 2009, 5; Ylijoki 2004, 72, 153-154). Thus, joining the tribe of ethnologists, we not only learn to do ethnology, but might also bring something new to the table and gradually affect the whole discipline.

Instead of tribes and traditions, I have written about communities and practices. By studying how shared practices are gateways to communities in the museum field and how the new members might want to change or conserve the practices of their communities, I might be describing similar cultural patterns as Leena Paaskoski, just by using different words. But when you think of it, there are differences in the nuances. The word "tribe" has the implication of something uncomplicated, traditional, maybe natural or fixed, whereas I have wanted to stress the diversity, complexity and the dynamism of the communities and practices in the museum world. "Traditions" can be a useful word, but the things that matter to people - in this case, to museum professionals, museum activists or visitors, and things that tie their communities together - can also be very trivial, everyday doings and happenings, and therefore I think that "practices" is even better a word.

The mundane practices and small changes to them - be it in the field of museums or ethnology - can also have a real effect on things. You may well ask, how ethnological research has changed since the invention of personal computers - when you didn't have to retype you whole dissertation every time you wanted to edit something - or how does it affect ethnology when it is conducted from home offices with less chances of daily conversations with your colleagues.

So, honouring the styles of doing museums, and understanding that the museum practices change and their cultural meanings need contextualisation, for a moment, let us imagine that I could create a fantasy museum of Finnish museum history - what would there be?

Based on my research, I would say that it might show photographs of 19th century museum men in their suits and ties sitting in their offices smoking pipes, the grandiosity of Finnish museum architecture, perhaps art historians discussing how works of art should be arranged on the walls, and most certainly it would portray the museum storage rooms and the volume of objects of different sorts and sizes stored in cardboard boxes and silk papers. I think we would see handwritten museum catalogues and index cards, cupboards full of dia slides, archives of newspaper clippings, and the evolution of multimedia equipment used in exhibitions. There might be sound effects from guided tours, exhibition openings or coffee breaks. We would be able to browse through different digital content: the first museum websites from a couple of decades ago, IT-based collection catalogues and virtual museums. And if I would get to decide, there would also be a range of local heritage museums, home museums, and private or "amateur" museums represented in some form. There would also definitely be offices with messy desks, photocopies, bookshelves, people sitting at computers and in meetings - and people sitting at computers having meetings. 
I find the mental image of a museum exhibition presenting museums fascinating. It would highlight the change and stratification of museum practices, but also the human input behind the cultural heritage management. Museums are products of social practices that change with time and vary in different societies and communities and understanding this allows us to examine more critically where our different ideas of museums come from.

Hakamies, Inkeri. 2021. Practicing Museums: Museum People, Museum Work and Change in Practice. Helsinki: University of Helsinki. http://urn.fi/URN:ISBN:978-951-51-7518-2.

\section{Bibliography}

Alberti, Samuel J. M. M., Blackwell, Alice, Davidson, Peter, Goldberg, Martin \& Swinney, Geoffrey N. 2019. "The Art and Science of Replication. Copies and Copying in the MultiDisciplinary Museum." In Museums as Cultures of Copies. The Crafting of Artefacts and Authenticity, edited by Brita Brenna, Hans Dam Christensen and Olav Hamran, 13-26. Routledge Research in Museum Studies. London \& New York: Routledge.

Borowiecki, Karol Jan, Forbes, Neil, \& Fresa, Antonella. 2016. "Section 1: Introduction." In Cultural Heritage in a Changing World, edited by Karol Jan Borowiecki, Neil Forbes, and Antonella Fresa, xix-xxix. Cham: Springer International Publishing. https://doi. org/10.1007/978-3-319-29544-2.

Boon, Marcus. 2019."'Towards a future museum of copying." In Museums as Cultures of Copies. The Crafting of Artefacts and Authenticity, edited by Brita Brenna, Hans Dam Christensen and Olav Hamran, 253-266. Routledge Research in Museum Studies. London \& New York: Routledge.

Brenna, Brita. 2019.“Contact, Copy and Model in Eighteenth-century Trondheim."In Museums as Cultures of Copies. The Crafting of Artefacts and Authenticity, edited by Brita Brenna, Hans Dam Christensen and Olav Hamran, 27-39. Routledge Research in Museum Studies. London \& New York: Routledge.

Gradén, Lizette \& O'Dell, Tom. 2018a. "Striving to Grow. The Challenge of Re-imagining Nordic Heritage in North America." Scandinavian Studies, 90(3), 436-460. https://doi. org/10.5406/scanstud.90.3.0436.

Gradén, Lizette \& O'Dell, Tom. 2018b. "Hip heritage and contemporary tastes. Packaging the Nordic in the American cultural market." Nordisk Museologi 1(2018), 45-61. https://doi. org/10.5617/nm.6397.

Kalin, Nadine M. 2016. "Disneyfied/ized Participation in the Art Museum." In Disney, Culture, and Curriculum, edited by Sandlin, J.A., and Garlen, J.C., 193-207. London \& New York: Routledge. https://doi.org/10.4324/9781315661599.

Kirshenblatt-Gimblett, Barbara. 1998. Destination Culture. Tourism, Museums, and Heritage. Berkeley: University of California Press.

Kuurne, Jouni. 2010. Unelmien koti. Nukketalojen pienoismaailmat. Helsinki: Suomalaisen Kirjallisuuden Seura.

Lönnqvist, Bo. 2011. "Nukkekaapin arvoitus." In Aineen taikaa. Näkyvän ja näkymättömän kulttuurin jäljillä, edited by Aila Nieminen, Pia Olsson, Helena Ruotsala and Katriina Siivonen, 179-191. Helsinki: Suomalaisen Kirjallisuuden Seura. 
McCarthy, Conal. 2015. "Introduction: Grounding Museum Studies. Introducing Practice." In The International Handbooks of Museum Studies: Museum Practice, edited by Sharon Macdonald and Helen Rees Leahy, xxxv-lii. Chichester: John Wiley \& Sons Ld. https:// doi.org/10.1002/9781118829059.wbihms200.

Paaskoski, Leena. 2009. "Kansatieteen heimokulttuuri: Lectio praecursoria Helsingin yliopistossa 6.6.2008." Elore, 16(1). https://doi.org/10.30666/elore.78784.

Reckwitz, Andreas. 2002. "Toward a Theory of Social Practices. A Development in Culturalist Theorizing." European Journal of Social Theory 5(2), 243-263. https://doi. org/10.1177/13684310222225432.

Smith, Laurajane. 2015. "Theorizing museums and heritage visiting." In The International Handbooks of Museum Studies: Museum Theory, edited by Andrea Witcomb and Kyle Message, 459-484. Chichester: John Wiley \& Sons.

Ylijoki, Oili-Helena. 2004. Akateemiset heimokulttuurit ja noviisien sosialisaatio. Tampere: Vastapaino. 